Artikel Penelitian

\title{
Pengaruh Ekstrak Daun Kersen Terhadap Kadar Malondialdehid Rattus norvegicus Model Diabetes Tipe II Induksi Streptozotocin-Nicotinamide
}

\author{
Dewi Karita $^{1 *}$, Refni Riyanto ${ }^{2}$, Indrasto Histopaedianto ${ }^{3}$, Yusuf Indra Kusuma ${ }^{1}$, Galih \\ Rosfianto Putra', Yoni Trismawan ${ }^{1}$
}

1) Departemen Biokimia, Fakultas Kedokteran Universitas Muhammadiyah Purwokerto, Indonesia

2) Departemen Anestesi, Fakultas Kedokteran Universitas Muhammadiyah Purwokerto, Indonesia

3) Departemen Bedah, Fakultas Kedokteran Universitas Muhammadiyah Purwokerto, Indonesia

*Corresponding author: dewikarita@gmail.com

\section{ABSTRACT}

Background: the prevalence of Diabetes Mellitus continues to increase every year. Pharmacological therapy that has been carried out with synthetic drugs and insulin injections tends to be expensive and can have a hypoglycemic effect. The use of traditional medicine in type 2 DM is considered to have lower side effects, is easy to obtain and many plants have more than one pharmacological effect. Purpose: kersen leaf contain various types of flavonoid compounds that have the potential to be used as antioxidants to prevent the increase in Malondialdehyde (MDA) due to cell damage caused by the effects of type II diabetes mellitus. Methods: 3 groups of rats were given 3 different doses $(0,3 \mathrm{mg} / \mathrm{gBW}, 0,5 \mathrm{mg} / \mathrm{gBW}$ dan 0,7 $\mathrm{mg} / \mathrm{gBW}$ of kersen leaves while the other 3 groups were negative control (were only given aquabidest), normal control (no treatment) and positive control (were given metformin). Result: there is an effect on the administration of ethanol extract of cherry leaves with an optimal dose of $0.7 \mathrm{mg} / \mathrm{gBW}$. Conclusion: kersen ethanol extract can lower MDA level in rat with type II diabetes mellitus.

Keywords: kersen leaf, malondialdehyde, type II diabetes mellitus

\begin{abstract}
ABSTRAK
Latar Belakang: prevalensi Diabetes Melitus terus meningkat setiap tahunnya. Terapi farmakologi yang selama ini dilakukan dengan obat sintetik dan suntikan insulin cenderung mahal dan dapat menimbulkan efek hipoglikemik. Penggunaan obat tradisional pada DM tipe 2 dinilai memiliki efek samping yang lebih rendah, mudah diperoleh dan banyak tanaman yang memiliki efek farmakologi lebih dari satu. Tujuan: daun kersen mengandung berbagai jenis senyawa flavonoid yang berpotensi digunakan sebagai antioksidan untuk mencegah peningkatan Malondialdehid (MDA) akibat kerusakan sel akibat efek diabetes mellitus tipe II. Metode: 3 kelompok tikus diberi 3 dosis $(0,3 \mathrm{mg} / \mathrm{gBB}, 0,5 \mathrm{mg} / \mathrm{gBB}$ dan $0,7 \mathrm{mg} / \mathrm{gBB})$ daun kersen yang berbeda sedangkan 3 kelompok lainnya kontrol negatif, kontrol normal (tanpa perlakuan) dan kontrol positif (diberi metformin). Hasil: ada pengaruh pada pemberian ekstrak etanol daun kersen dengan dosis optimal $0,7 \mathrm{mg} / \mathrm{gBB}$. Simpulan: ekstrak etanol kersen dapat menurunkan kadar MDA pada tikus dengan diabetes melitus tipe II.
\end{abstract}

Kata kunci: daun kersen, malondialdehid, diabetes melitus tipe II 


\section{PENDAHULUAN}

Diabetes melitus (DM) adalah penyakit metabolik kronik yang ditandai dengan peningkatan kadar gula darah dan berakibat jangka panjang pada kerusakan jantung, vaskular, ginjal, mata dan juga saraf $(1,2)$. Berdasarkan prevalensi penyakit diabetes di Indonesia, provinsi DKI Jakarta menempati urutan tertinggi dengan $(3,4 \%)$ diikuti Kalimantan Timur (3,1\%), dan Daerah Istimewa Yogyakarta (3,1\%)(3).

Penggunaan obat tradisional dinilai relatif lebih aman dibandingkan dengan obat konvensional. Kelebihan lainnya adalah obat tradisional memiliki efek samping yang relatif minimal pada ramuan yang kandungannya beraneka ragam serta memiliki efek sinergis, banyak tumbuhan yang mungkin memiliki lebih dari satu efek farmakologis, hal ini lebih sesuai untuk berbagai penyakit metabolik dan generatif. Kelemahannya dari obat tradisional antara lain efek farmakologisnya lemah, bahan baku yang belum terstandar, dan belum dilakukan serangkaian penelitian untuk memastikan efektivitas dosis terapi dan keamanannya (4).

Peroksidasi lipid adalah suatu proses yang terjadi akibat proses pembakaran yang tidak sempurna sehingga terjadi peningkatan Reactive Oxygen Species (ROS) yang merupakan suatu radikal bebas dan akan menghasilkan produk hydrogen peroksida. Hidrogen peroksida dapat menyebabkan dekomposisi produk aldehid yang bersifat toksik. Salah satu produk aldehid utama yang terbentuk ialah Malondialdehida (MDA) (5). MDA merupakan salah satu biomarker yang menandakan adanya kondisi stress oksidatif dalam tubuh, seperti penyakit kronis contohnya diabetes. Mudah diukur dan reliable. MDA sendiri merupakan produk peroksidasi lipid yang paling mutagenik atau memiliki potensi menimbulkan mutasi gen (6).

Daun Kersen (Muntingia calabura L) merupakan tanaman yang mudah untuk tumbuh, berasal dari selatan Mexico, Amerika Selatan dan negara-negara di asia tenggara contohnya Indonesia, Malaysia dan Filipina. Kersen (Muntingia calabura L. folium) adalah tanaman yang mengandung berbagai senyawa flavonoid, tanin dan chalcone. Hasil penelitian sebelumnya, daun kersen mengandung berbagai macam jenis senyawa flavonoid yang berpotensi untuk pengobatan, seperti antidiabetik, anti-inflamasi, antikanker dan antipiretik (7). Pada penelitian ini bertujuan untuk mengetahui efek ekstrak daun kersen terhadap kadar MDA pada tikus diabetes mellitus tipe II yang diinduksi streptozotocin-nicotinamide.

\section{METODE}

Penelitian ini merupakan penelitian eksperimental dengan menggunakan rancangan posttest only with randomized controlled group design. Tempat pelaksanaan penelitian di Fakultas Kedokteran Universitas Muhammadiyah Purwokerto. Penelitian ini menggunakan hewan coba Tikus Putih (Rattus norvegicus) Galur Wistar dengan kriteria inklusi:1) Tikus jantan 2) Umur 2-3 bulan, 3) Berat badan 100-200g 4) Kondisi sehat (aktif dan tidak cacat). Penelitian ini telah disetujui oleh komisi etik Fakultas Kedokteran Universitas Muhammadiyah Purwokerto Nomor: KEPK/FK/047/IX/ 2021, 30 ekor tikus dibagi menjadi 6 kelompok, setelah aklimatisasi selama 7 hari masing-masing kelompok diberi perlakuan (kecuali kelompok normal) yaitu pemberian streptozotocin-nicotinamide dengan dosis $65 \mathrm{mg} / \mathrm{kgBB}$ secara 
intraperitoneal dan ditunggu 5 hari setelah induksi dilakukan.

Pembuatan ekstrak daun kersen (Muntingia calabura L. folium) dilakukan dengan metode maserasi (8). Kemudian diberikan ekstrak daun kersen secara intraperitoneal selama 14 hari dengan dosis $0,3 \mathrm{mg} / \mathrm{gBB}, 0,5 \mathrm{mg} / \mathrm{gBB}$ dan $0,7 \mathrm{mg} / \mathrm{gBB}$. Pengambilan sampel darah dilakukan pada hari ke 15 penelitian. Darah diambil dari sinus orbitalis dengan pipet hematokrit sebanyak $3 \mathrm{ml}$ dan ditampung dalam vacutainer EDTA.

Tabel 1. Pengukuran sampel MDA

\begin{tabular}{llll}
\hline & Blanko & Standar & Sampel \\
\hline Aquabidest & $400 \mu \mathrm{L}$ & - & - \\
Standard & - & $400 \mu \mathrm{L}$ & - \\
Serum & - & - & $400 \mu \mathrm{L}$ \\
Reagen & 1600 & 1600 & 1600 \\
\hline
\end{tabular}

Blanko, standar, dan sampel di vortex kemudian diinkubasi pada suhu $90^{\circ} \mathrm{C}$ selama 80 menit. Didinginkan dengan air es batu selama 10 menit lalu ditambahkan tiap tabung dengan $1600 \mu \mathrm{L}$ reagen ekstrak butanol kemudian divortex. Selanjutnya dilakukan sentrifugasi $3500 \mathrm{rpm}$ selama 15 menit. Supernatan diambil $750 \mu \mathrm{L}$ dan dibaca pada panjang gelombang 510, 532, $560 \mathrm{~nm}$ pada alat spektrofotometer shimadzu u-vis 1280. Dari hasil yang didapat kemudian dimasukan ke pengolah data statistik, lalu diuji dengan saphiro-wilk dan One way Anova test dengan confidence interval $95 \%$.

\section{HASIL}

Hasil uji normalitas dengan uji saphiro wilk dengan $\mathrm{p}$ value $>0,05$ pada seluruh kelompok perlakuan sehingga sebaran datanya normal. Untuk mengetahui hasil dari uji beda hasil MDA antar kelompok perlakuan dapat dilihat pada tabel 2 .

Tabel 2. Kadar MDA

\begin{tabular}{|c|c|}
\hline Kelompok & $\begin{array}{c}\text { MDA } \\
(\mu \mathrm{mol} / \mathrm{L}) \\
\text { mean } \pm \text { SD }\end{array}$ \\
\hline I (kontrol p & \\
\hline II (kon & $32.14 \pm$ \\
\hline III (kontrol normal) & $54.75 \pm 42.77 \quad 0,012$ \\
\hline (dosis & $81.47 \pm 28.98$ \\
\hline $0,3 \mathrm{mg}$ & \\
\hline $\mathrm{V}(\operatorname{dosis} 0,5 \mathrm{mg} / \mathrm{gBB})$ & $40.71 \pm 19.18$ \\
\hline $\begin{array}{l}\mathrm{VI} \quad(\text { dosis } \\
\mathrm{mg} / \mathrm{gBB})\end{array}$ & $\begin{array}{c}25.06 \pm \\
10.09\end{array}$ \\
\hline \multicolumn{2}{|c|}{ *uji dengan One way anova, CI 95\% } \\
\hline \multicolumn{2}{|c|}{$\begin{array}{l}\text { Tabel } 2 \text { menunjukkan bahwa terdapat } \\
\text { perbedaan yang signifikan antar kelompok } \\
\text { perlakuan. Nilai tertinggi kadar MDA } \\
\text { terdapat pada kelompok } 1 \text { yang merupakan } \\
\text { kelompok kontrol positif, sedangkan pada } \\
\text { kelompok yang diberi ekstrak etanol daun } \\
\text { kersen kelompok dengan kadar MDA } \\
\text { tertinggi yaitu pada kelompok yang diberi } \\
\text { dosis } 0,3 \mathrm{mg} / \mathrm{gBB} \text {. Sementara, kadar MDA } \\
\text { terendah terdapat pada kelompok } 6 \text { yaitu } \\
\text { kelompok yang diberi ekstrak daun kersen } \\
\text { dengan dosis } 0,7 \mathrm{mg} / \mathrm{gBB} \text {. }\end{array}$} \\
\hline
\end{tabular}

\section{PEMBAHASAN}

Pada keadaan normal, radikal bebas terbentuk di dalam tubuh sangat lambat dan perlahan. Kondisi radikal bebas yang meningkat melebihi kemampuan pertahanan endogen, maka akan terjadi ketidakseimbangan antara jumlah radikal bebas dengan antioksidan endogen, sehingga terjadilah ketidakstabilan (stres) oksidatif. Stres oksidatif menyebabkan peroksidasi lipid yang berlebihan. Hasil dari peroksidasi lipid adalah MDA, sehingga meningkatnya peroksidasi lipid dapat menyebabkan kadar MDA dalam tubuh meningkat (6). 
Patogenesis diabetes mellitus tipe 2 klasik biasanya dimulai dengan resistensi insulin, yang secara bertahap meningkatkan kebutuhan sel beta untuk melakukan sekresi insulin. Normoglikemia berhasil dipertahankan oleh peningkatan kompensasi dalam sekresi insulin pada sebagian besar orang. Namun, pada individu yang rentan menjadi DM, sel beta akhirnya gagal untuk melakukan kompensasi resistensi insulin, mengakibatkan intoleransi glukosa, dan akhirnya, hiperglikemia puasa dan gejala diabetes yang jelas terlihat (9). Keadaan tersebut disebut sebagai resistensi insulin yang merupakan penyebab dari DM tipe 2 . Resistensi insulin dapat ditemukan sebagai hasil dari keadaan obesitas, penuaan serta kurangnya aktivitas fisik (10).

Kerusakan yang terjadi pada sel beta pankreas dapat meningkatkan radikal bebas termasuk ROS melalui beberapa jalur yaitu advanced glycation end-products (AGEs), ekspresi dari reseptor, jalur poliol, aktivasi dari isoform protein kinase dan penurunan antioksidan, (11) sehingga akan meningkatkan produksi MDA. Diperlukan adanya antioksidan untuk dapat menurunkan dan menyeimbangkan efek negatif dari radikal bebas. Penderita DM dengan peningkatan produksi radikal bebas yang disebabkan oleh mekanisme yang melibatkan hiperglikemia mengakibatkan peningkatan produksi superoksida pada mitokondria. Selain itu, auto-oksidasi glukosa juga menghasilkan superoksida dan juga terjadi peningkatan Low Density Lipoprotein teroksidasi pada endotel. Stres mekanik pada hipertensi akan menginduksi translokasi p47 phox dan kemudian terjadi aktivasi NADPH oksidase. Aktivasi reseptor AT1 oleh angiotensin II juga mengakibatkan aktivasi NADPH oksidase dan superoksid juga diproduksi akibat aktivasi oleh 12-LO (lipooksigenase) dalam VSMCs (vasculer smooth muscle
cells)(12).

Malondialdehida (MDA) adalah produk sekunder utama, lebih mutagenik dan lebih stabil dibanding aldehid lainnya sehingga dianggap sebagai petanda terbaik untuk mendeteksi stres oksidatif pada lipid (13). Beberapa pendekatan obat secara konvensional hingga mencakup epigenetik sudah mulai dilakukan, termasuk mulai dikembangkannya beberapa penelitian dengan bahan-bahan herbal untuk diabetes. (14) Pada penelitian Syahara et al., yang menyimpulkan bahwa ada pengaruh pemberian ekstrak ethanol daun kersen (Muntingia calabura L. folium) mampu menurunkan kadar glukosa darah pada tikus putih galur wistar dengan dosis $500 \mathrm{mg} / \mathrm{kg}$ yang diberikan 14 hari, hal ini juga mendukung dari indikator perbaikan DM yang lain. (15) Demikian juga penelitian yang dilakukan oleh Herlina bahwa efek ekstrak ethanol daun kersen (Muntingia calabura L. folium) dapat menurunkan kadar glukosa darah dengan dosis 260 $\mathrm{mg} / \mathrm{kgBB}$ (16).

Studi ini menemukan dosis 0,7 $\mathrm{mg} / \mathrm{gBB}$ memberikan perbedaan diantara kelompok perlakuan dengan hasil kadar MDA paling rendah, yaitu 25.06 10.09 $\mu \mathrm{mol} / \mathrm{L}$. Perbandingan kadar MDA tikus antar kelompok perlakuan menunjukan bahwa kerusakan sel yang diakibatkan oleh efek diabetes menyebabkan peningkatan radikal bebas. Belum diketahuinya kadar normal MDA tikus menyebabkan kami menggunakan kelompok kontrol normal untuk mengetahui kadar MDA pada tikus yang tidak diberi perlakuan, yaitu $54,75 \pm 42,77 \mu \mathrm{mol} / \mathrm{L}$.

Daun kersen banyak mengandung senyawa flavonoid antara lain flavon, flavonon, flavan, dan biflavan yang memberikan efek antidiabetes dan 
sitotoksik. Senyawa fenolik, tannin dan flavon merupakan senyawa utama yang berperan sebagai antioksidan (17). Studi lain juga menunjukkan efek hipoglikemik yang signifikan pada mencit Mus musculus $L$ setelah pemberian selama 2 jam, menunjukkan penurunan hingga $24 \%$ kadar glukosa darah hewan coba yang mendapat perlakuan pemberian ekstrak daun kersen (18). Penelitian oleh Jamal menyimpulkan flavonoid sebagai antioksidan dapat memiliki efek hipoglikemik dengan beberapa mekanisme memberikan rangsangan pelepasan dan sensitasi insulin, menghambat absorbsi glukosa, berperan meregulasi enzim-enzim untuk metabolisme karbohidrat serta peningkatan ambilan glukosa pada jaringan perifer (19).

Daun kersen juga memiliki kandungan saponin yang cukup dominan. Saponin merupakan inhibitor dari enzim $\alpha$ glukosidase dengan mengubah glukosa menjadi karbohidrat, menjadikan glukosa darah menurun, zat ini juga memiliki fungsi inhibitor untuk GLUT-2 sehingga menurunkan absorbsi glukosa di intestinal. Kandungan saponin ini akan berperan menurunkan stres oksidatif dikarenakan fungsinya sebagai antioksidan tersebut (20).

\section{SIMPULAN}

Ekstrak etanol kersen dapat menurunkan kadar MDA pada tikus dengan diabetes melitus tipe II.

\section{UCAPAN TERIMA KASIH}

Penelitian ini didanai oleh dana hibah LPPM Universitas Muhammadiyah Purwokerto No: A.11-III/622-S.Pj./LPPM/ XII/2020.

\section{KONFLIK KEPENTINGAN}

Penulis menyatakan mereka tidak memiliki konflik kepentingan, dan tidak ada afiliasi atau koneksi dengan atau dengan entitas atau organisasi apa pun, yang dapat menimbulkan pertanyaan bias dalam diskusi dan kesimpulan naskah.

\section{REFERENSI}

1. Stumvoll M, Goldstein BJ, Haeften TW Van. Haeften_Pathogenesis of type 2 diabetes.pdf. Lancet. 2005;365:1333-46.

2. Chatterjee S, Khunti K, Davies MJ. Type 2 diabetes. Lancet. 2017;389(10085):2239-51.

3. RISKESDAS NBP dan P. Laporan_Nasional_RKD2018_FIN AL.pdf. Badan Penelitian dan Pengembangan Kesehatan. 2018. p. 123-30.

4. Katno. Tingkat manfaat, keamanan dan efektifitas tanaman obat dan obat tradisional. Karanganyar: Balai Besar Penelitian dan Pengembangan Tanaman Obat dan Obat Tradisional (B2P2TOOT). Badan Penelit dan Pengemb Kesehat Dep Kesehat RI. 2018;

5. Kashinakunti, Kollur, Kallaganada, Rangappa, Ingin. Comparative study of serum MDA and vitamin C levels in non-smokers, chronic smokers and chronic smokers with acute myocardial infarction in men. 2011. p. 993-998.

6. Ayala A, Muñoz MF, Argüelles S, Ayala A, Mu\&\#xf1;oz MF, Arg\&\#xfc;elles S, et al. Lipid Peroxidation: Production, Metabolism, and Signaling Mechanisms of Malondialdehyde and 4-Hydroxy-2-Nonenal. Oxid Med Cell Longev. 2014;2014(May 
2014):1-31.

7. Mahmood ND, Nasir NLM, Rofiee MS, Tohid SFM, Ching SM, Teh LK et al. Muntingia calabura: A review of its traditional uses, chemical properties, and pharmacological observations. Pharm Biol. 2014;52(12):1598-623.

8. Herlina. Science \& Technology Indonesia Antidiabetic Activity Test Of Ethanolic Seri Leave' s ( Muntingia Calabura L .) Extract In Male Rats Induced By Alloxan. Sci Technol Indones. 2018;3:7-13.

9. Wysham C, Shubrook J. Beta-cell failure in type 2 diabetes: mechanisms, markers, and clinical implications. Postgrad Med. 2020;132(8):676-86.

10. PERKENI. Pedoman pengelolaan dan pencegahan diabetes melitus tipe 2 di Indonesia. Perkeni. 2019. 133 p.

11. Oliveira $\mathrm{S}$, Monteiro-Alfredo $\mathrm{T}$, Silva S, Matafome P. Curcumin derivatives for Type 2 Diabetes management and prevention of complications. Arch Pharm Res. 2020;43(6):567-81.

12. Siswonoto S. Hubungan Kadar Malondialdehid Plasma Stroke Iskemik Akut Correlation of Plasma Malondyaldehyde With Program Pasca Sarjana Program Pendidikan Dokter Spesialis I. 2008;1-116.

13. Anggraeni $\mathrm{S}$, Setyaningrum $\mathrm{T}$, Listiawan MY. Significant Different Level of Malondialdehyde (MDA) as Oxydative Stress Marker in Severity Groups of Acne Vulgaris. Berk Ilmu Kesehat Kulit dan
Kelamin. 2017;29(1):36-43.

14. Ling C. Epigenetic regulation of insulin action and secretion - role in the pathogenesis of type 2 diabetes. $\mathrm{J}$ Intern Med. 2020;288(2):158-67.

15. Syahara S, Harahap U, Widyawati T. Activity of Muntingia calabura Leaves Ethanolic Extract on Glucose and Insulin Blood Levels in Streptozotocin-induced Rat. Asian J Pharm Res Dev. 2019;7(4):8-11.

16. Herlina H. Antidiabetic Activity Test of Ethanolic Seri Leave's (Muntingia Calabura L.) Extract in Male Rats Induced by Alloxan. Sci Technol Indones. 2018;3(1):7-13.

17. Puspitasari AD, Wulandari RL. Aktivitas Antioksidan dan Penetapan Kadar Flavonoid Total Ekstrak Etil Asetat Daun Kersen (Muntingia calabura). J Pharmascience. 2017;4(2):167-75.

18. Stevani H., Thamrin H. A. BNH. Efektivitas Rebusan Daun Kersen (Muntingia calabura L.) Terhadap Penurunan Kadar Glukosa Darah Pada Mencit (Mus musculus). Media Farm. 2017;13(1).

19. Jamal H, Ansari WH RS. Chalcones: Differential effects on glycogen contents of liver, brain and spinal cord in rats. Bio Med. 2015;1(2):107-15.

20. Fiana N, Oktaria D. Pengaruh Kandungan Saponin dalam Daging Buah Mahkota Dewa ( Phaleria macrocarpa ) terhadap Penurunan Kadar Glukosa Darah. Majority. 2016;5(4):128-32. 